Max Planck Institute for Innovation and Competition Research Paper No. 17-11

Jorge L. Contreras and Peter Georg Picht

PATENT ASSERTION ENTITIES AND LEGAL

EXCEPTIONALISM IN EUROPE AND THE UNITED

STATES, A COMPARATIVE VIEW 


\section{Patent Assertion Entities and Legal Exceptionalism in Europe and the United States, a Comparative View}

\author{
Jorge L. Contreras \\ University of Utah
}

\author{
Peter Georg Picht \\ University of Zurich
}

\begin{abstract}
Patent assertion entities are playing an increasing role in patent policy and patent litigation, both in the U.S. and Europe. Analyzing the resulting case law, mainly in the SEP/FRAND context, this article shows similarities as well as differences in the approaches taken by U.S. and EU courts.
\end{abstract}

Keywords-patent, NPE, PAE, FRAND, SEP, remedy, injunction, royalty, Huawei

\section{INTRODUCTION}

It is nearly impossible to discuss patent policy today without mentioning the phenomenon of patent assertion entities (PAEs). PAEs are firms that are in the business of patent monetization: they acquire patents from a variety of sources and then seek to collect revenue from companies manufacturing and selling covered products. More pejoratively, PAEs are known as patent "trolls". 1 PAEs typically obtain patents from third parties: failed start-ups, bankruptcy estates, companies abandoning all or part of their business activity, individual inventors, or operating companies that are simply seeking to earn revenue from under-utilized patent assets [5][7]. In some cases, operating companies may retain an interest in patents transferred to PAEs in an arrangement that has been referred to as "privateering" [41][42]. One recent study found that approximately $80 \%$ of patents asserted by PAEs were obtained from operating companies [19]. Unlike operating firms, the principal reason that most PAEs acquire patents is to assert them for the purpose of generating revenue, either through licensing, litigation settlements or damages awards [3][13].

One source reports that in 2016, approximately $69 \%$ of the patent cases filed in the U.S. were filed by PAEs [1]. While there is some disagreement regarding the precise number, size and impact of PAE lawsuits, most studies suggest that a significant portion of recent U.S. patent litigation is attributable to PAEs [3][10][6][7][8][13]. PAE activity is significant in Europe as well. One recent study finds that PAEs accounted for approximately $19 \%$ of patent assertions between 2000 and 2008 in Germany and 9\% of patent assertions between 2000

${ }^{1}$ The term non-practicing entity (NPE) is also used in this context, though NPEs, which are entities that do not manufacture or sell products covered by their patents, include universities and government R\&D labs. PAEs are generally considered a subset of NPEs. and 2013 in England and Wales [9]. Additional questions regarding PAE assertions in Europe arise with the approach of EU-wide injunctions under the new Unified Patent Court (UPC) system which could come into force soon [19][20]. ${ }^{2}$

PAE litigation has been characterized by many commentators and policy makers as a distinct phenomenon, differing in many ways from ordinary patent litigation among operating entities. This distinction, and the perceived threat posed by PAEs, has even been noticed by the U.S. Supreme Court. ${ }^{3}$ On one hand, critics fear that PAE litigation clogs the judicial system, drains resources from research, innovation and product development, harms small businesses, and increases the cost of products and services across industries [11][12]. Defenders of PAEs counter that these entities are operating within their legal rights by asserting patents duly issued by governmental agencies, and that their ability to monetize under-utilized patents provides needed liquidity to the market and helps innovators who are unable to compete directly with large enterprises [8][14].

In this article, we do not attempt to solve the intractable policy questions surrounding the PAE phenomenon Instead, we ask whether the judicial law that has evolved concerning PAEs is substantively different than the law governing patent litigation more generally. ${ }^{4} \mathrm{We}$ focus in part on litigation concerning patents that are essential to industry standards such as $\mathrm{Wi}-\mathrm{Fi}$ and 4G LTE because, with the advent of the global "smart phone wars", standards-related litigation has become increasingly prominent [31], there is evidence that substantial

${ }^{2}$ As of this writing, the UPC system is on hold as the United Kingdom (due to the "Brexit" process and the recent elections) and Germany (due to a request by the Constitutional Court) have suspended the ratification process.

${ }^{3}$ As discussed in Part II.A below, the Supreme Court took explicit notice of PAEs in its 2006 decision in eBay v. MercExchange [15]. This year, in TC Heartland v. Kraft Foods, the Supreme Court, without mentioning PAEs by name, severely limited the ability of patent holders to bring suit in jurisdictions such as the notorious Eastern District of Texas, that have traditionally been viewed as magnets for PAE litigation [16][17].

${ }^{4}$ Our focus is on the laws of the United States and Europe, though PAE litigation is rapidly becoming a global phenomenon. Likewise, we focus on the law developed through judicial decisions. There have been numerous proposals, primarily in the United States, to curb PAE litigation through legislative action [3]. 
numbers of standards-related patent lawsuits have been initiated by PAEs [21][19][22], and several of the legal adjustments made by courts with respect to PAEs have arisen in this area.

\section{PAEs AND THE LAW IN THE UNITED STATES}

\section{A. Injunctions}

Prior to eBay $v$ MercExchange [15], the holder of a valid U.S. patent was more or less assured of obtaining an injunction to prevent an infringer from producing or selling infringing products. This longstanding rule was altered in eBay, in which the Supreme Court introduced a 4-factor equitable test that lower courts must now apply before issuing an injunction. It provides that an injunction will not issue unless the plaintiff can demonstrate:

(1) that it has suffered an irreparable injury;

(2) that remedies available at law [i.e., monetary damages] are inadequate to compensate it for that injury;

(3) that considering the balance of hardships between the plaintiff and defendant, a remedy in equity is warranted; and (4) that the public interest would not be disserved by the award of an injunction.

In a separate opinion concurring with the Court's result, four justices expressed their concern with PAE suits, observing that in recent years "[a]n industry has developed in which firms use patents not as a basis for producing or selling goods but, instead, primarily for obtaining licensing fees" (p. 396). The justices explained their support for the new injunction standard in view of the fact that such entities could use injunctive relief as "a bargaining tool to charge exorbitant fees to companies that seek to buy licenses to practice the patent" (id.). Accordingly, these justices seemingly urge lower courts to view requests for injunctive relief by PAEs with a degree of skepticism.

The principal difficulty that PAEs experience in seeking injunctive relief under $e B a y$ is Factor 2: the patent holder must show that its injury cannot adequately be compensated through an award of monetary damages. Because PAEs have no business other than asserting patents for financial gain, it has been argued that, by definition, they are fully compensated by monetary damages, making the issuance of an injunction unnecessary [13][30]. Under this theory, permitting PAEs to seek injunctive relief would simply give them additional and inappropriate leverage to seek higher royalties in licensing negotiations [30].

As a result, the ability of PAEs to obtain injunctive relief in the U.S. after $e B a y$ has been significantly curtailed. One recent study finds that while permanent injunctions were issued in approximately $75 \%$ of U.S. patent cases, PAEs were successful in obtaining injunctive relief only $16 \%$ of the time [23].

\footnotetext{
${ }^{5}$ That is, an allegedly infringing product manufacturer would likely accept a license at a higher rate if the patentee could threaten to block its sale of products through an injunction.
}

Interestingly, this result does not hold with respect to exclusion orders issued by the U.S. International Trade Commission (ITC). As an administrative agency, the ITC is authorized to prohibit the importation into the U.S. of goods that infringe U.S. intellectual property rights [28]. Such an exclusion order will only be issued if the asserted patent rights affect a domestic industry. However, the statute provides that 'licensing' activity is sufficient to constitute a domestic U.S. industry, and ITC exclusion orders have routinely been issued in favor of patents held by PAEs [30][36].

\section{B. Damages}

\section{1) Lost Profits}

In the U.S., a patentee that proves infringement of its valid patent is entitled to recover "damages adequate to compensate for the infringement, but in no event less than a reasonable royalty". In addition to damages based on a reasonable royalty, patent holders may also attempt to recover damages based on the profits that they have foregone as a result of the infringement (so-called "lost profits" damages). In theory, lost profits damages award the patent holder the entire monopoly value of excluding competitors from the marketplace, while reasonable royalty damages only award it a market-based fee for allowing competition [25]. As explained by the U.S. Court of Appeals for the Federal Circuit, "[n]ormally, if the patentee is not selling a product, by definition there can be no lost profits" [26]. And because PAEs do not themselves sell products, courts have generally not awarded lost profits damages to PAEs [27].

\section{2) Reasonable Royalties}

Without lost profits, PAEs may only seek reasonable royalty damages. In the U.S., reasonable royalty damages are intended to reflect the incremental value that a patented technology contributes to a product [33]. Such damages are often calculated using an analytical framework in which the court or jury seeks to determine what royalty the parties would have agreed in a hypothetical negotiation immediately prior to the time of infringement [34].

But while lost profits (the entire profit on a patented product) are often assumed to be higher than reasonable royalties (the royalty payable to a single patent holder), litigation data show that NPEs have consistently obtained median reasonable royalty damages awards substantially in excess of those obtained by practicing entities [13][12][27]. For example, Pricewaterhouse Coopers reports that between 2011 and 2016, median damage awards in suits brought by NPEs were 3.8 higher than awards in suits brought by practicing entities [27].

There are several possible explanations for this discrepancy. First, PAEs, which lack an internal product strategy, may select patents for enforcement based solely on their potential monetary value, rather than their strategic or market value to the plaintiff's product or business lines. Likewise, PAEs may bring suit against any market participant

\footnotetext{
${ }^{6}$ These statistics include awards to non-PAE NPEs such as research universities, which have been responsible for some of the largest recent patent awards.
} 
based solely on its attractiveness as a financial target, without regard to strategic, supply chain or customer relationships (i.e., a component vendor might be reluctant to sue its largest customer, notwithstanding that customer's infringement of the vendor's patents). ${ }^{7}$ Third, PAEs, which have no product markets to defend, are less susceptible to counterclaims and injunctive threats against their own products, making "total war" possible without reciprocal consequences. And finally, PAEs, as repeat players, may simply be better at patent litigation than one-off producers. Thus, unlike the typical manufacturing firm, PAEs (or their owners) may have a ready arsenal of litigators, claim charts, briefs, economics experts and the like to bring to bear at costs that reflect economies of scale, as well as a dedicated litigation war chest.

In view of these considerations, some scholars have suggested that U.S. patent damages law be recalibrated to reduce inappropriately high PAE recoveries. One such proposal would allow a patentee to recover substantial monetary damages only when it has undertaken efforts to produce or market the patented invention [29]. This limitation would effectively impose a so-called "working requirement" on reasonable royalty damages, a result that scholars argue is consistent with the historical development of damages law in the United States [29]. ${ }^{8}$ If such an approach were adopted (something that would likely require a statutory amendment), it would have a significant impact on the incentives for PAEs to bring patent suits and, indeed, to remain in business at all.

Another, less drastic, proposal would revamp the reasonable royalty damages framework [34] when "willing licensors" (patent holders that are willing to grant licenses to infringers) sue infringers that did not intentionally copy the patented technology ("innocent" infringers) [30]. Under this revised framework, reasonable royalty damages would be based solely on information available to the parties in a hypothetical negotiation occurring on the date that the infringer became committed to using the patented technology [30]. This approach has already gained traction in the context of standards-essential patents (damages should be based on the royalty rate that would have been agreed by the parties before the patented technology was adopted in a standard [33][35]), but could also be extended to patents outside the standards area [30].

\section{Patent Transfers to PAEs}

As noted above, most PAEs obtain their patents from others: operating companies, research institutions, individual inventors, and the like [5][7]. Ordinarily, when assets are transferred from one party to another, the transferee is not obligated to fulfill promises made by the transferor to third

7 In fact, some large customers in industries such as semiconductor manufacturing require their vendors to refrain from suing the customer's other vendors, in order to assure a stable supply chain.

${ }^{8}$ Working requirements condition the ability to enforce a legal right on the active exploitation of that right. Because PAEs do not "work" their patents through manufacture or sale of products, a number of proposals have been made seeking to limit PAEs' ability to enforce patents based on non-working. parties absent a binding covenant or contractual commitment to do so. Nonetheless, PAEs that have tried to disavow such promises, especially in the case of standards-essential patents, have encountered resistance both from industry and U.S. antitrust agencies. The first such instance that gained widespread attention occurred in 2008, when a PAE known as Negotiated Data Solutions (N-Data) acquired patents covering IEEE's 802.3 Fast Ethernet standard [38]. The original patentee, National Semiconductor, had committed to IEEE that it would license the patents to manufacturers of compliant products at a flat rate of $\$ 1,000$. After acquiring the patents, NData announced that it would seek higher rates. Following industry complaints, the U.S. Federal Trade Commission brought an action alleging that N-Data's disavowal of National's earlier $\$ 1,000$ commitment constituted an unfair method of competition and an unfair act or practice under Section 5 of the FTC Act [39]. Similar concerns were raised when newly-formed Rockstar Bidco sought to acquire a large portfolio of patents from then-bankrupt Nortel Networks without adhering to Nortel's prior licensing commitments to standards bodies [31]. In order to secure the assets, Rockstar eventually agreed to honor those commitments.

As a result of actions like these, PAEs that acquire patents that were once subject to standards-based licensing commitments typically agree to abide by those commitments. Nevertheless, the legal theories that would require these commitments on downstream transferees of patents are untested in the courts and remain uncertain, at best [32].

A different set of antitrust concerns has recently arisen in the context of "privateering", in which operating companies transfer patents to PAEs for assertion, usually while retaining some financial interest in the outcome of the litigation [41][42]. Commentators have theorized that a range of antitrust claims could potentially be brought against operating companies and PAEs that conspire to raise rivals' costs through patent transfers such as these [42].

In one recent case Apple alleged that Nokia, the holder of a large patent portfolio covering wireless telecommunications standards, conspired with Acacia and other PAEs to divide Nokia's portfolio and assert its patents separately [40]. Apple alleges that this conduct was intended to "diffuse and abuse" Nokia's portfolio by forcing manufacturers to defend multiple suits and collecting "far more in royalties than [Nokia] could have sought on its own". Such privateering conduct was alleged to have violated both Nokia's commitments to the standards body (ETSI) and U.S. antitrust law [40].

\section{PAES AND THE LAW IN EUROPE}

\section{A. Overall treatment by courts}

As in the U.S., PAEs have been involved in significant patent litigation in Europe [9], including significant litigation involving SEPs [22]. Accordingly, a number of European scholars have proposed restrictions on PAE litigation activity [43] [44][45]. Courts, however, have not generally been hostile toward PAEs [43][46]. On the contrary, courts in Europe seem hesitant to draw patent law or competition law consequences 
based solely on the fact that a party is a PAE. German courts, for instance, have stated explicitly that they see no reason to treat PAEs differently from any other patent owners [47]. Hence, for the time being, the general rules of EU and Member State law on SEP enforcement and FRAND licensing are the yardstick for the lion's share of PAE activity in Europe. Whether this attitude may change in the face of increasing PAE activity remains to be seen.

\section{B. Injunctions}

It must be kept in mind that, at present, there is no such thing as "EU patent law". Instead, patent laws and their rules on injunctions are national and may differ from Member State to Member State, although the European Patent Convention [50] and a shared patent law tradition provide a certain degree of homogeneity. German patent law, for instance, does not limit the right to an injunction in the case of patent infringement through an eBay-like balancing test [44][51]. An infringer in Germany can, however, resist the entry of an injunction by successfully raising defenses such as the competition law-based entitlement to a (compulsory) FRAND license [43]. ${ }^{9}$

The starting point for assessing SEP/FRAND cases is the prohibition of abuses of market dominance in Art. 102 TFEU because SEP ownership can indicate - but does not necessarily result in - dominance. Against this background, the success of a SEP-owning PAE claiming an injunction depends to a large extent on whether the PAE (claimant) and the standardimplementer/patent infringer (defendant) respectively comply with the conduct requirements established by the European Court of Justice (ECJ) in its 2015 Huawei v. ZTE decision [52] (a case that did not involve a PAE). According to the ECJ a SEP owner is able to seek an injunction in spite of having made the promise to grant FRAND licenses, but "[...], in order to prevent an action for a prohibitory injunction [...] from being regarded as abusive, the proprietor of an SEP must comply with conditions which seek to ensure a fair balance between the interests concerned" [52]:

- Firstly, cannot, without infringing Article 102 TFEU, bring an action for a prohibitory injunction or for the recall of products against the alleged infringer without notice or prior consultation with the alleged infringer, even if the SEP has already been used by the alleged infringer.

- Secondly, after the alleged infringer has expressed its willingness to conclude a licensing agreement, it is for the proprietor of the SEP to present a specific, written offer for a license on FRAND terms.

- Thirdly, the standard-implementer, in turn, must diligently respond to the SEP holder's offer, in accordance with recognized commercial practices in the field and in good faith, abstaining, in particular, from delaying tactics. Should the alleged infringer not accept the offer, it must submit a specific counter-offer that itself is FRAND.

\footnotetext{
${ }^{9}$ It is worth noting that this competition law defense under European law is in addition to any contractual claims that a party may have with respect to its entitlement to a FRAND license.
}

Furthermore, where the alleged infringer is using the teachings of the SEP before a licensing agreement has been concluded, it must, from the point at which its counter-offer is rejected, provide appropriate security the amount of which is calculated on the basis of the royalties offered by the implementer. The alleged infringer must be able to render an account in respect of its acts of use.

- Where no agreement is reached on the details of the FRAND terms following the counter-offer of the alleged infringer, the parties may, by common agreement, request that the amount of the royalty be determined by an independent third party, by decision without delay.

In consequence (and simplifying somewhat): The patentee can obtain an injunction if the standard-implementer fails to comply with the above scheme. If the blame lies with the patentee, no injunction is issued and the implementer has to be granted a FRAND license. If both parties comply but cannot reach an agreement, the implementer is still entitled to a FRAND license, the conditions of which can be set by an "independent third-party", such as a court or an arbitration tribunal. Courts (and maybe at some point the EU legislator or the EU Commission) are now in the process of working out details of the Huawei framework. Interestingly, the majority of these post-Huawei cases involves PAEs and they are frequently granted injunctions due to the implementer's failure to comply with the Huawei conduct requirements. Appellate courts have, however, suspended the enforcement of a substantial part of these decisions because they were not in agreement with the lower courts' interpretation of the Huawei conduct requirements or their determination of FRAND licensing terms.

\section{Damages}

As the other elements of patent law, damages are mainly governed by EU Member State law. Taking § 139 German Patent Law as an example, the patent owner can recover monetary damages from an infringer that intentionally or negligently makes use of a patent under $\S \S 9,10$ of the German Patent Law (PatG) [53][54][55]. To determine the specific amount of monetary damages to be paid by the infringer, the patent owner can select between three different calculation methods pursuant to $\S 139$ (2) PatG. The first method looks at the "difference in wealth" on the part of the patent owner caused by the infringement ("Differenzmethode") [56]. If it uses this approach to recover lost profits, the patent owner must prove that it could have obtained the amount of profits claimed in the absence of the infringing activity [55]. The second calculation method, often called the "objective calculation of damages", is widely used in practice [55]. It refers to the reasonable royalties that could be obtained from a third person for the use of the patent [53][54]. The third method aims at the disgorgement of the infringer's profits. Since it is only a calculation method and not a standalone claim, it must be proven that the IPR owner incurred actual losses [53]. Irrespective of the calculation method, courts are permitted to estimate the damages to be paid pursuant to $\S 287$ 
German Code of Civil Procedure if the patent owner is not able to substantiate its financial losses [54].

Claims for damages in the SEP/FRAND context are not directly subject to the Huawei conduct requirements as the ECJ found that "Article 102 TFEU must be interpreted as not prohibiting [...] an undertaking in a dominant position and holding a SEP [...] from bringing an action for infringement against the alleged infringer of its SEP and seeking the rendering of accounts in relation to past acts of use of that SEP or an award of damages in respect of those acts of use" [52]. This view has been supported in subsequent decisions rendered by German courts [56][57][58][59]. Accordingly, a SEP proprietor is not acting abusively under Article 102 TFEU if it brings an action for damages, even without having notified the standard implementer of the infringement and without having offered a FRAND license. However, the Huawei requirements may have an indirect impact on the extent to which damages and a rendering of accounts are due. While some courts limit all damages to FRAND levels in the presence of a FRAND commitment, there is also case law holding that, in case of a patentee's failure to comply with Huawei, damages are limited to the FRAND royalty level only for the period after the SEP proprietor's abusive refusal to license. Claims for information and the rendering of accounts must, in this event, be limited to what is necessary for determining these FRAND-based damages [56]. In any case, since a PAE does, by definition, not produce or market products, the "lost profits" it can recover are only such profits as the entity could have realized by licensing the asserted patent [54][60].

\section{Patent Transfers to PAEs}

European case law discusses in some detail whether the transfer of a patent portfolio to a PAE, especially if motivated by the attempt to maximize licensing profits through „privateering“ strategies, runs afoul of competition law. For example, the Dusseldorf Regional Court has found $[56][61][62]$ that such portfolio transfers are not subject to merger control. Furthermore, such a portfolio transfer does not violate Art. 101, 102 TFEU merely because it is performed for the purpose of improving the transferor's bargaining power or the overall return on the patent portfolio in question. Nor is the (PAE) transferee generally obliged to continue the licensing practice and maintain the licensing conditions of the former patentee. This being said, limitations on the transferee's conduct can arise from a FRAND commitment made by the prior patent owner, as the German courts state very clearly that competition law is violated where a transferee asks for licensing conditions above a FRAND level or discriminates among implementers [56][61][62]. British case law seems to take, for the time being, a slightly different turn as Birss J. holds in Unwired Planet v. Huawei, which involved SEPs transferred to a PAE by an operating company, that only substantial deviations from FRAND royalty levels amount to a violation of European competition law [63][64]. The key question is where to draw the line beyond which FRAND transgressions become anticompetitive. According to the Dusseldorf Regional Court in Unwired Planet v. Samsung [56][61][62], this line can be crossed not only based on the PAE's licensing conditions, but also by an accumulation of licensing demands made by the PAE-transferee combined with those made by the transferor (with respect to its remaining portfolio), and potentially other SEP owners. Hence, the court obliges the PAE to take into consideration at least the terms that are imposed by the transferor, so as to avoid a FRAND violation by the cumulative conditions. It is evident that these considerations are of great importance to royalty stacking situations in general.

Courts are quite strict when it comes to the potential termination of a FRAND commitment after a patent (portfolio) transfer: The parties to such transactions are obliged by EU competition law to ensure that the PAE-transferee continues to be bound by any prior FRAND commitment made by holders of the transferred patents [56][61][62]. This can, in particular, be achieved through clauses obliging the transferee to honor the transferor's FRAND commitment, to make such a commitment itself to the relevant SSO, to abstain from seeking non-FRAND terms, and to impose the same obligations on any future transferee of the patent(s) in question [56][61][62]. While binding a PAE-transferee to an existing FRAND commitment can be required by competition law, precise agreements regarding the PAE's future royalty demands may be less acceptable. Such agreements can amount to anticompetitive price-fixing if, for example, a minimum royalty rate is defined. Calculating the purchase price for the patents in question by estimating the PAE's licensing revenues based on a pre-defined "applicable royalty rate" did not, however, amount to price fixing in [CASE] because the transferee was effectively free to charge royalty rates that differed from the "applicable" rate [56][61][62].

Since PAE-driven patent enforcement is usually preceded by the transactional acquisition of the asserted patents, it does not come as a surprise that defendants may try to attack the validity of these transactions, the patent ownership of the PAEs, and, hence, their standing in court. However, German courts have considered the registration of a patent owner, even a PAE, in the patent register to be a strong indication of the patent's ownership [65][66]. In consequence, courts have refused to pay much heed to allegations that patent transactions are, on their face, invalid [48][49][56][67][68]. ${ }^{10}$ Although not limited to the context of PAEs, this view of the courts is certainly supportive of their litigation efforts.

\section{CONCLUSIONS}

PAEs are playing an increasing role in patent litigation in both the U.S. and Europe. In response, courts have issued a variety of decisions in cases brought by PAEs. In the U.S., courts, led by the concurring justices in the Supreme Court's seminal eBay decision, have expressed concern regarding the impact of PAEs on litigation as well as the economy, more broadly. While courts have generally stopped short of enacting PAEspecific rules, a number of limitations on the remedies available to PAEs have been established through pre-existing doctrines limiting monetary recovery and injunctive relief

\footnotetext{
${ }^{10}$ These decisions discuss many facets of patent ownership registration. For additional discussion, see [69].
} 
applicable to non-practicing patent holders. In Europe, courts have been more reluctant to view PAEs differently than other patent holders. German courts, in particular, tend to follow a patentee-friendly approach, irrespective of the patentee's business model. This difference may, on the one hand, result from differences in the roles that courts in the U.S. and Europe see themselves playing. In the U.S., for example, courts are charged with assessing the impact on the public interest of issuing injunctions in patent cases, an analysis that must necessarily involve assessments of the incentive value of patents as well as the economic impact of judicial rulings not only on the litigants, but to consumers and other market actors. In Europe, courts may view their roles as more circumscribed, interpreting rules that govern the relationships between holders of patent rights, but not extending to broader social or economic factors. These differences may, on the other hand, be exacerbated by the relatively greater impact of PAE litigation on U.S. courts and markets. With comparatively lower damages awards and fewer patent suits overall, a more hands-off approach by European courts may be viewed as acceptable. As a general tendency, competition law is more prominent in the EU while patent law is employed more intensely in by US courts. This may be due to the fact that, so far, patent law is not harmonized within the EU. Whether these differences will be maintained following the still very likely - introduction of the UPC and its creation of a Europe-wide litigation system in a combined market larger than the U.S. remains to be seen.

\section{REFERENCES}

[1] RPX Corp., 2015 Report: NPE Litigation, Patent Marketplace, and NPE Cost (2016).

[2] Unified Patents, 2016 Annual Patent Dispute Report (2017).

[3] U.S. Fed. Trade Comm'n, Patent Assertion Entity Activity (2016).

[4] J.R. Allison, M.A. Lemley, D.L. Schwartz, "How Often do NonPracticing Entities Win Patent Suits?", Berkeley Tech. L.J. at *6-9 (2017).

[5] J.R. Allison, M.A. Lemley, J. Walker, "Patent Quality and Settlement Among Repeat Patent Litigants", 99 Geo. L. J. 677 (2011).

[6] D.L. Schwartz, J.P. Kesan, "Analyzing the Role of Non-Practicing Entities in the Patent System", 99 Cornell L. Rev. 425 (2014).

[7] C.A. Cotropia, J.P. Kesan, D.L. Schwartz, "Unpacking Patent Assertion Entities”, 99 Minn. L. Rev. 649, 669-70 (2014).

[8] M. Risch, "Patent Troll Myths", 42 Seton Hall L. Rev. 4567 (2012).

[9] B.J. Love, C. Helmers, F. Gaessler, M. Ernicke, "Patent Assertion Entities in Europe", in Patent Assertion Entities and Competition Policy (D. Daniel Sokol, ed., 2017)

[10] S. Jeruss, R. Feldman, J. Walker, "The America Invents Act 500: Effects of Patent Monetization Entities on US Litigation", 11 DUKE L. \& TECH. REV. 357 (2013).

[11] Exec. Office of the President, Patent Assertion and U.S. Innovation (2013).

[12] F. Scott Morton, C. Shapiro, "Patent Assertions: Are we any closer to Aligning Reward to Contribution?", NBER Innov. Policy and the Economy Conf. (2015).

[13] M.A. Lemley \& A.D. Melamed, "Missing the Forest for the Trolls", 113 Colum. L. Rev. 2117 (2013).
[14] M. Sabattini, "NPEs vs Patent Trolls, How to Build a Healthy Innovation Ecosystem", IP Watchdog, Feb. 4, 2015.

[15] eBay, Inc. v. MercExchange LLC, 547 U.S. 388 (2006).

[16] TC Heartland LLC v. Kraft Foods Group Brands LLC, 581 U.S. (2017).

[17] G. Quinn, "SCOTUS Reverses Federal Cirtuit in TC Heartland, Patent Venue in State of Incorporation", IPWatchdog, May 22, 2017.

[18] J.R. Allison, M.A. Lemley, D.L. Schwartz, "Understanding the Realities of Modern Patent Litigation", 92 Tex. L. Rev. 1769 (2014).

[19] European Commission Joint Research Centre, JRC Science for Policy Report: Patent Assertion Entities in Europe (2016).

[20] A. Johnson, "Why Europe's New Patent Regime Could be an Exciting One for NPEs", IAM Blog, Oct. 14, 2014, http://www.iammedia.com/Blog/Detail.aspx?g=d1f4ed0a-23c3-47b5-998c$\underline{\mathrm{a} 35 \mathrm{~b} 5 \mathrm{~d} 710440}$.

[21] J.L. Contreras, "Assertion of Standard Essential Patents by NonPracticing Entities", in Patent Assertion Entities and Competition Policy (D.D. Sokol, ed., 2017).

[22] J.L. Contreras, F. Gaessler, C. Helmers, B.J. Love, "Litigation of Standards-Essential Patents in Europe: A Comparative Analysis", 32 Berkeley Tech. L.J. _ (2017)

[23] C.B. Seaman, "Permanent Injunctions in Patent Litigation After eBay: An Empirical Study", 101 Iowa L. Rev. 1949 (2016).

[24] 35 U.S.Code $\S 284$.

[25] M.A. Lemley, "Distinguishing Lost Profits from Reasonable Royalties", 51 Wm. \& Mary L. Rev. 655 (2009).

[26] Rite-Hite Corp. v. Kelley Co., 56 f.3d 1538, 1554 (Fed. Cir. 1995) (en banc).

[27] PricewaterhouseCoopers, "2017 Patent Litigation Study: Change on the horizon?" (2017).

[28] 19 U.S.C. $\S 1337$.

[29] O. Liivak, "When Nominal is Reasonable: Damages for the Unpracticed Patent", 56 Boston Coll. L. Rev. 1031 (2015).

[30] W.F. Lee, A.D. Melamed, "Breaking The Vicious Cycle of Patent Damages", 101 Cornell L. Rev. 385 (2016).

[31] Natl. Research Council, Intellectual Property Challenges For StandardSetting in the Global Economy (K. Maskus and S.A. Merrill, eds., 2013).

[32] J.L. Contreras, “A Market Reliance Theory for FRAND Commitments and Other Patent Pledges", 2015 Utah L. Rev 479 (2015).

[33] Ericsson Inc. v. D-Link Sys., 2013 U.S. Dist. LEXIS 110585 (E.D. Tex. 2014).

[34] Georgia-Pacific Corp. v. U.S. Plywood Corp, 318 f. Supp. 1116, 1120 (S.D.N.Y. 1970), modified and aff'd, 446 f.2d 295 (2d Cir. 1971), cert. denied, 404 U.S. 870 (1971).

[35] C. Shapiro, "Navigating the patent thicket: cross-licenses, patent pools and standard setting", in Innovation Policy and the Economy, Vol. 4, at 119 (A.B. Jaffe, J. Lerner \& S. Stern, eds., 2004).

[36] In re. Certain Silicon-on-Insulator Wafers, Inv. No. 337-TA-1025, Order No. 13: Initial Determination Finding Complainant Silicon Genesis Corporation has Satisfied Contingently the Economic Prong of the Domestic Industry Requirement (Feb. 8, 2017).

[37] J. Bock, "Patent Quantity", 38 U. Hawaii L. Rev. 287 (2016).

[38] Negotiated Data Solutions LLC, No. C-4234, 2008 WL 4407246 (F.T.C. Sept. 22, 2008).

[39] 15 U.S.C. § 45(a)(1) (2012).

[40] Apple Inc. v. Acacia Research Corp., Complaint. No. 16-CV-7266 at 2, 4 (N.D. Cal., filed Dec. 20, 2016).

[41] E. Hovenkamp, T.F. Cotter, "Anticompetitive Patent Injunctions", 100 Minn. L. Rev. 871 (2016).

[42] M.S. Popofsky, M.D. Laufert, "Antitrust Attacks on Patent Assertion Entities", 79 Antitrust L.J. 445 (2014).

[43] C. Osterrieth, Patent-Trolls in Europa - braucht das Patentrecht neue Grenzen?, GRUR 2009, 540. 
[44] A. Ohly, „Patenttrolle” oder: Der patentrechtliche Unterlassungsanspruch unter Verhältnismäßigkeitsvorbehalt?, GRUR Int 2008, 787.

[45] Kraßer/Ann, Patentrecht, $\S 3$ Rn. 62 (adopting a less critical view toward PAEs).

[46] R. Lundie-Smith/G. Moss, Bard v Gore: to injunct, or not to injunct, what is the question? Is it right to reward an infringer for successfully exploiting a patent?, GRUR Int 2013, 400

[47] OLG Düsseldorf, Jan. 13, 2016, I-15 U 66/15 - Sisvel/Haier, Rn. 11.

[48] LG Düsseldorf, March 31, 2016, 4a O 73/14 - Saint Lawrence/Vodafone, Rn. 189, stressing that the ECJ itself does not differentiate between PAEs and other patentees.

[49] LG Düsseldorf, March 31, 2016, 4a O 126/14 - Saint Lawrence/Vodafone, Rn. 183.

[50] http://www.epo.org/law-practice/legal-texts/epc.html.

[51] § 139 PatG.

[52] Huawei v. ZTE, Eur. Court of Justice, Case C-170/13 (2015).

[53] Mes/Mes, § 139 PatG N 6, 121.

[54] Benkard/Grabinski/Zülch, § 139 PatG N 13 et seq.

[55] Busse/Keukenschrijver, § 139 PatG N 97.

[56] LG Düsseldorf, Jan. 19, 2016 - Case No. 4b O 120/14 Unwired Planet/Samsung.

[57] LG Mannheim, Jan. 29, 2016 - Case No. 7 O 66/15, para. II, 1.

[58] LG Mannheim, Jan. 8, 2016 - Case No. 7 O 96/14, para. 79.
[59] LG Mannheim, July 1, 2016 - Case No 7 O 209/15, para. III, IV, 1.

[60] BGH GRUR 70, 296, 298.

[61] LG Düsseldorf, Jan. 19, 2016, 4b O 122/14 - Unwired Planet/Samsung, Rn. $227 \mathrm{ff}$.

[62] LG Düsseldorf, Jan. 19, 2016, 4b O 123/14 - Unwired Planet/Samsung, Rn. 204 ff.

[63] J.L. Contreras, "Global Markets, Competition and FRAND Royalties: The Many Implications of Unwired Planet v. Huawei", Antitrust Source (forthcoming 2017).

[64] P.G. Picht, "Unwired Planet/Huawei: A Seminal SEP/FRAND Decision From the UK", Max Planck Institute for Innovation \& Competition Research Paper No. 17-07, https://papers.ssrn.com/sol3/papers.cfm?abstract_id=2967183\#\#.

[65] BGHZ 197, 196 Rn. 51 ff. - Fräsverfahren.

[66] Kühnen, GRUR 2014, 137.

[67] LG Mannheim, Nov. 27, 2015, 2 O 106/14 - Saint Lawrence/Deutsche Telekom, Rn. 106 ff.

[68] OLG Düsseldorf, May 9, 2016, I-15 U 35/16 - Saint Lawrence/Vodafone, Rn. $9 \mathrm{ff}$.

[69] P.G. Picht, Vom materiellen Wert des Immateriellen Immaterialgüterrechte als Kreditsicherheiten im nationalen und internationalen Rechtsverkehr, 2017 (forthcoming). 